\title{
The origins of water sources in the region of Annaba: confirmation using isotopic tools
}

\author{
LASSAAD GHRIEB ${ }^{1}$, LARBI DJABRI ${ }^{1}$, HICHAM ZERROUKI ${ }^{1}$, \\ AZZEDINE HANI ${ }^{1}$ \& ANTONIO PULIDO BOSCH ${ }^{2}$ \\ 1 Laboratory of Water Resource and Sustainable Development University of Annaba, Algeria \\ ghrieblassaad@yahoo.fr \\ 2 University of Almeria, Spain
}

\begin{abstract}
The studied area contains several superficial or deep water tables, which constitute the main sources of groundwater. The complexity of the exchange between groundwater and superficial water, as well as the casting of urban and industrial wastes remain unclear and require the application of isotopic techniques. Hence, a campaign involving 48 samples was conducted. We attempted to find the links between those groundwaters. We noticed that the water levels of oxygen $18\left({ }^{18} \mathrm{O}\right)$ range from $-6.5 \%$ in Orelait to $0.12 \%$ in Oued Meboudja. The majority of oxygen-18 values are homogenous and less than $-5 \%$. However, some values belong to the evaporated water area, indicating an enrichment of these waters. The isotopic study showed that evaporation is important in the studied region.
\end{abstract}

Key words groundwater, isotopic tools, evaporation, oxygen-18, superficial or deep water tables

\section{INTRODUCTION}

The lower valley of Oued Seybouse consists of Plio-Quaternary formations (sand, pebbles and clay) and metamorphic formations (gneiss, schists, marbles). The first formations contain spatially extended aquifers, while the latter contain very limited ones forming three terrace levels of 5 to 15 and $150 \mathrm{~m}$ thickness based on Numidian sandstones, Triassic carbonates and salt formations Djabri (1996).

The aquifers drainage by the river results in mixtures of the groundwater and surface water. The intense agricultural activity causes the return of irrigation water, often polluted, to the wadi. In addition, discharges of industrial and urban wastewater are carried throughout the valley. The use of isotopic tools in a context of a disturbed anthropic activity is a way to integrate the importance of water transits.

The present work aims to determine the origins of water sources and the evolution of the mineralization using an isotopic tool especially for a hydraulically linked aquifer.

\section{LOCATION}

The studied area is located in northeastern Algeria (Fig. 1). It is bordered on the north by the Mediterranean Sea, in the south by Drean, on the east by the River Mafragh and on the west by the Fetzara lake. The aquifer is mainly supplied from the west by surface water which came from the Edough mountain.

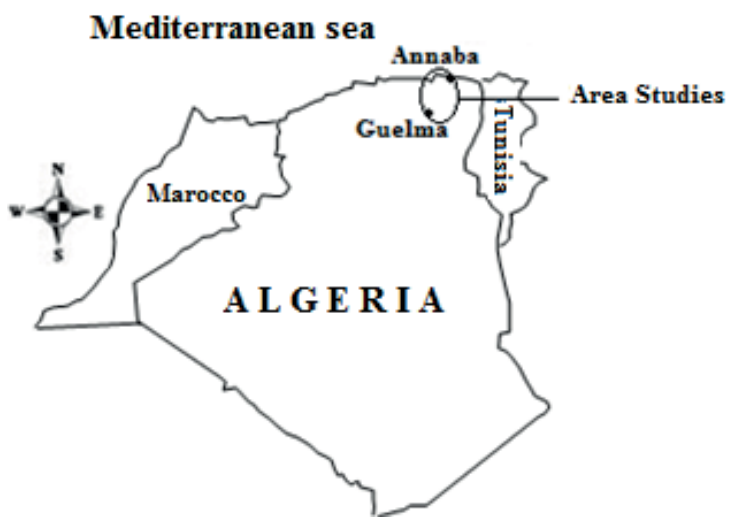

Fig. 1 Geographic location of the studied area. 


\section{GEOLOGY}

The studies in the region show the existence of two types of formation: metamorphic and sedimentary. Geological outcrops are dated from Paleozoic to Quaternary.

The arrangement of these formations revealed two aquifers (Fig. 2) communicating with each other mainly via the River Meboudja:

- The surperficial layer of Annaba (SLA): contained sandy-clay formations including sand lenses, compact grey clays constituting the bedrock. These lenses are frequent near the river of Seybouse and on the periphery of outcrops of the Numidian sandstones.

The groundwater is free, except for some points where it is captive under clay levels. The thickness of the free groundwater can reach $18 \mathrm{~m}$. This water is collected by drillings (in its deepest part) and sinks (in its free part).

- The high terraces alluvial groundwater: stretches along the Numidian massives in the west and the south of Annaba. These gravelly and stony alluviums with clay matrix contain very important aquifer opportunities in the western part, with the Lake Fetzara. Over 200 wells are located in this part. This water is captured by irrigation or drinking water wells resulting in significant pumping (Hani 2003).

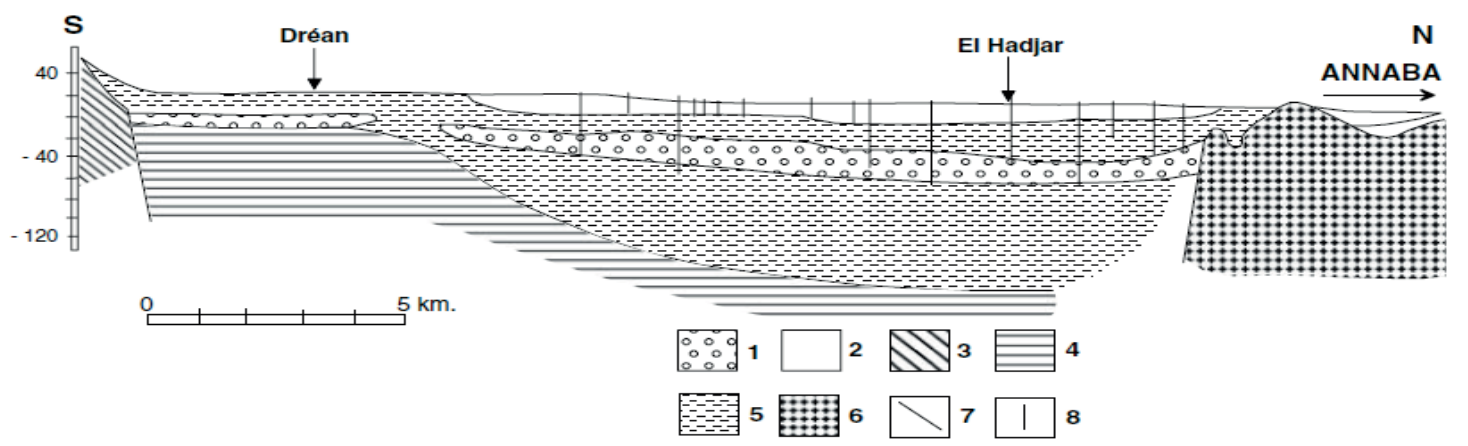

Fig. 2 Geologic cross-section of the studied area. Legend: 1, Clay loam with sand past (groundwater); 2 , Plio-Quaternary detrital clay; 3, Metamorphic Socle (micashiste, gneisses, marbles); 4, Numidian sandstone; 5, Pebble and gravel (deep aquifer); 6, Numidian or Paleocene clay; 7, Faults; 8, Drilling.

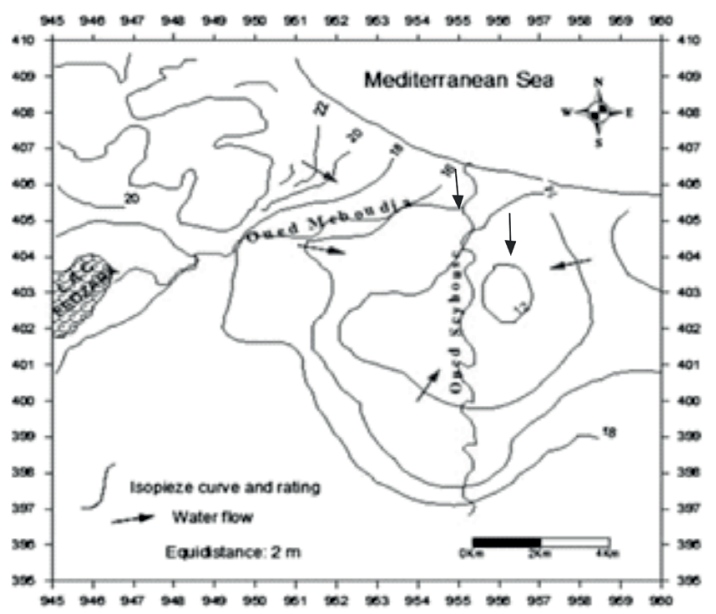

Fig. 3 Piezometric map of the superficial aquifer of Annaba.

\section{PIEZOMETRIC INDICATIONS OF THE SUPERFICIAL GROUNDWATER IN ANNABA}

Piezometric measurements made between the 5 and 10 January 2000 on 135 domestic levelled wells allow us to prepare the piezometric map by kriging.

The map (Fig. 3) shows that the water flow generally follows the topographic form of the studied area from the south to the north. However, at the mound Daghoussa, there is a 
Table 1 Results of isotopic analyses of ground and surface waters of the Seybouse Oued, June 1991.

\begin{tabular}{|c|c|c|c|c|c|}
\hline Water points & $\begin{array}{l}\text { Origin of } \\
\text { the water }\end{array}$ & $\begin{array}{l}\text { Types of } \\
\text { aquifers }\end{array}$ & $\begin{array}{l}\delta^{18} \mathrm{O}(\% 0) \\
\text { Smow }\end{array}$ & $\begin{array}{l}\delta^{2} \mathrm{H}(\%) \\
\text { Smow }\end{array}$ & Geographic area \\
\hline 1 APC Héliopolis & W & SA & -5.54 & -26.6 & Guelma \\
\hline 2 Oued Maiz to Héliopolis & $\mathrm{O}$ & & -6.04 & -44.5 & $/ /$ \\
\hline 3 Rejection Guelma & Ur & & -5.88 & -58.7 & $/ /$ \\
\hline 4 Fedjoudj Point & $\mathrm{O}$ & & -5.36 & -29.6 & $/ /$ \\
\hline 5 Belkeir Source & $\mathrm{S}$ & Lim & -5.8 & -33.2 & $/ /$ \\
\hline 6 Rejection Sucrerie & Ir & & -6.10 & -41.3 & $/ /$ \\
\hline 7 Seybouse to Bouhamra & $\mathrm{O}$ & & -4.9 & -36.5 & $/ /$ \\
\hline 8 Sidi Smair & W & Lim & -6.24 & -38.5 & $/ /$ \\
\hline 9 Djeballah & W & Lim & -5.24 & -37.7 & $/ /$ \\
\hline 10 Boussoura Oued & $\mathrm{O}$ & & -5.47 & -33.8 & $/ /$ \\
\hline 11 Seybouse railway & $\mathrm{O}$ & & -4.96 & -34.7 & $/ /$ \\
\hline 12 Aïn Sofra & $\mathrm{S}$ & $\mathrm{Cl}$ & -5.62 & -38.1 & $/ /$ \\
\hline 13 Oued Halia & $\mathrm{O}$ & & -5.32 & -27.7 & $/ /$ \\
\hline 14 Seybouse before Halia & $\mathrm{O}$ & & -5.08 & -39.28 & $/ /$ \\
\hline 15 Seybouse after Halia & $\mathrm{O}$ & $\mathrm{T}$ & -5.17 & -38.99 & $/ /$ \\
\hline 16 Nador Source & $\mathrm{S}$ & SA & -4.74 & -31.3 & $/ /$ \\
\hline 17 Nador & $\mathrm{W}$ & Lim & -5.30 & -40.6 & $/ /$ \\
\hline 18 Charef Source & $\mathrm{S}$ & & -4.81 & -30.1 & Bouchegouf \\
\hline 19 Charef Well & $\mathrm{W}$ & & -6.00 & -35.8 & $/ /$ \\
\hline 20 Seybouse before Mellah & $\mathrm{O}$ & & -5.1 & -37.6 & $/ /$ \\
\hline 21 Seybouse after Mellah & $\mathrm{O}$ & & -5.35 & -32.9 & $/ /$ \\
\hline 22 Mellah after Levurerie & $\mathrm{O}$ & & & & $/ /$ \\
\hline 23 Levurerie Rejection & $\mathrm{Ir}$ & & - & - & // \\
\hline 24 Mellah befor Levurerie & $\mathrm{O}$ & & -5.68 & -27.2 & $/ /$ \\
\hline 25 Seybouse to Boudaroua & $\mathrm{O}$ & & -5.78 & -34.2 & $/ /$ \\
\hline 26 Fragha Oued & $\mathrm{O}$ & & -5.72 & -34.0 & $/ /$ \\
\hline 27 Seybouse to Fragha & $\mathrm{O}$ & & -5.72 & -30.5 & $/ /$ \\
\hline 28 Seybouse to Mouhma & $\mathrm{O}$ & NS & -5.65 & -40.0 & $/ /$ \\
\hline 29 Well in Fernana & $\mathrm{W}$ & & -5.52 & -35.4 & $/ /$ \\
\hline 30 Well in Ousfata & $\mathrm{O}$ & & -5.78 & -32.6 & $/ /$ \\
\hline 31 Well before Chihani & $\mathrm{O}$ & & -5.85 & -39.3 & Annaba \\
\hline 32 Well in Chihani & $\mathrm{O}$ & & -5.31 & -35.2 & $/ /$ \\
\hline 33 Seybouse to Dréan & $\mathrm{O}$ & & -5.75 & -30.1 & $/ /$ \\
\hline 34 ECOTEC Rejection & $\mathrm{Ir}$ & & -4.21 & -27.6 & // \\
\hline 35 Seybouse to Dréan & $\mathrm{O}$ & & -5.71 & -38.7 & $/ /$ \\
\hline 36 Seybouse to Chbaïta & $\mathrm{O}$ & & -6.0 & -36.6 & $/ /$ \\
\hline 37 Seybouse to El-Hadjar & $\mathrm{O}$ & & -5.63 & -34.5 & $/ /$ \\
\hline 38 Seybouse to Oasis & $\mathrm{O}$ & & -5.55 & -37.7 & $/ /$ \\
\hline 39 Meboudja Pont Bouchet & $\mathrm{O}$ & & -2.24 & -22.1 & $/ /$ \\
\hline 40 Seybouse to Sidi Salem & $\mathrm{O}$ & & -4.54 & -29.0 & $/ /$ \\
\hline 41 S.N. METAL Rejection & Ir & & -3.48 & -23 & $/ /$ \\
\hline 42 ORELAIT Rejection & $\mathrm{Ir}$ & & -6.5 & -42.6 & // \\
\hline 43 Meboudja to Hadjar Diss & $\mathrm{O}$ & & +0.12 & -18.3 & $/ /$ \\
\hline 44 S.N.S 1st Rejection & Ir & & & & $/ /$ \\
\hline 45 S.N.S 2nd Rejection & $\mathrm{Ir}$ & & -5.6 & -50.3 & $/ /$ \\
\hline 46 Meboudja after S.N.S & $\mathrm{O}$ & & -1.82 & -13.2 & $/ /$ \\
\hline 47 Sidi amar industrial area & $\mathrm{Ir}$ & & -2.26 & -20.6 & $/ /$ \\
\hline 48 the entry of Annaba Source & $\mathrm{S}$ & $\mathrm{C}$ & -3.24 & -20.18 & $/ /$ \\
\hline
\end{tabular}

$\mathrm{S}$ A = Superficial aquifer, $\mathrm{C}=$ Cipolins; $\mathrm{Lim}=$ limestone; $\mathrm{Cl}=$ Clay; $\mathrm{T}=$ Trias; $\mathrm{NS}=$ Numidian sandstone; $\mathrm{O}=$ Oued; $\mathrm{S}=$ Sources; $\mathrm{Ir}=$ industrial Rejection; $\mathrm{Ur}=$ Urban Rejection; $\mathrm{W}=$ Well.

change in the flow direction; it is from the sea to the mainland. This trend is localized on the northern part of the map and indicates a possible groundwater supply by the sea (Zenati 1999). Furthermore, 
the presence of a depression highlights the influence of pumping on the groundwater level, they can contribute to the advancement of the salt bord.

\section{MATERIALS AND METHODS}

Forty-eight samples of groundwater and surface water, Wadi and discharges have been the subject of this work. The electrical conductivity was measured in situ using a multiparameter device (Multiline P3 pH / LF-SET) and a light sensor (SEBA KLL) for the measurement of the piezometric level. In this study we focus on the analysis of isotopes that were determined in the CDTN laboratory (Algiers). The samples were transported in a cooler at $4^{\circ} \mathrm{C}$.

\section{RESULTS}

The detailed results of isotopic analyses are reported in Table 1, according to:

- The water sample origin (source, sink, wadi, discharges, etc.);

- The aquifer type (alluvial, Triassic limestone, sandstone Numidian, ... etc.).

Deuterium and oxygen-18 were analysed in samples (Table 1).

The oxygen 18 content of the water varies between 18 and 6.5\% in ORELAIT discharges (Number 42 ) to $0.12 \%$ in Oued Meboudja (Number 43 ). The majority of oxygen-18 values are homologous and below 5\%. Ten water points $(11,16,18,34,39,40,41,43,46,47$ and 48) have levels lower than $5 \%$ and reach a value of $0.12 \%$. They were heated to varying degrees and correspond to the evaporated water (Souag 1989).

Water from sources 16, 18 and 48 was evaporated after rainfall during runoff before infiltration. The enrichment of the six other points of water $(3,14,15,17,20,45)$ is probably related to the fractionation during their use before discharge. (Water is more or less evaporated during its use before discharge and during domestic or industrial use, Craig and Cord 1965.)

Figure 4 shows the deuterium relationship based on oxygen-18 highlights and confirms the assumptions made above. The waters with homogeneous levels of oxygen-18 are aligned along a cloud on the line of precipitation of Tunis-Carthage station, adopting the form: $\delta^{2} H=8 \delta^{18} O+12$.

The waters of the 10 points called "the evaporated water" confirmed their evaporated stamp because the samples are aligned on the line with a slope of less than 8 and so they are in the field of evaporated water. The content in oxygen- 18 before evaporation was approximately $-5.5 \%$ (Fontes 1976).

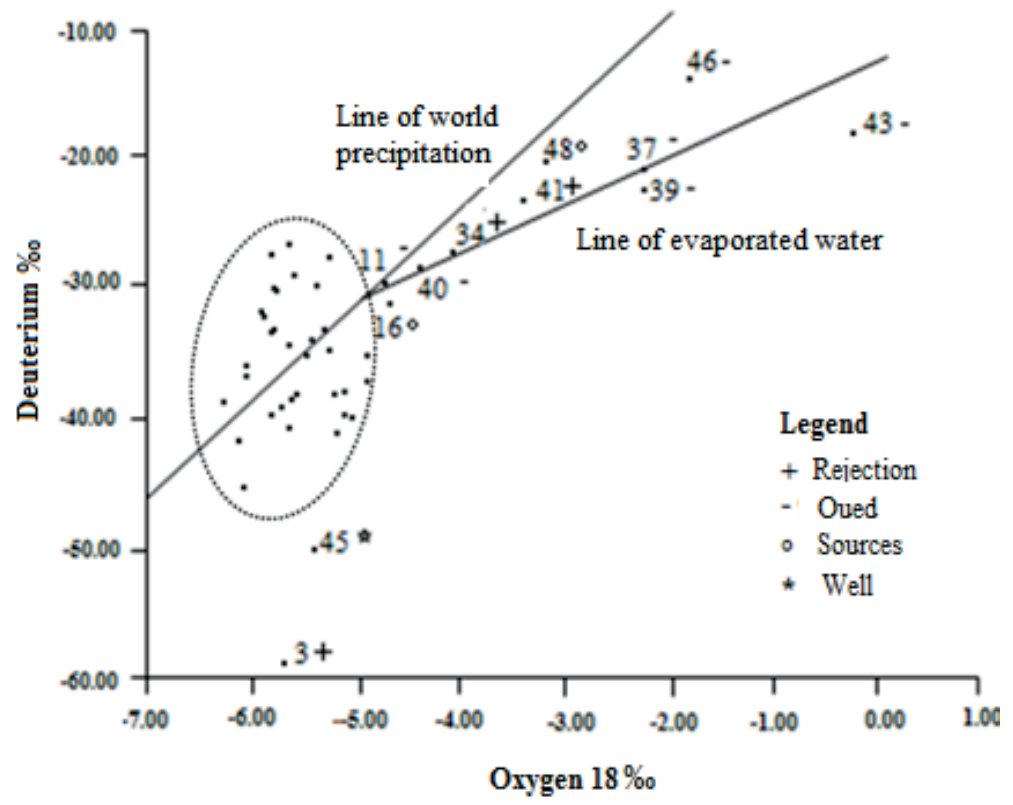

Fig. 4 The Deuterium-Oxygen 18 relationship. 
The distance between the water points ( 3 and 45) and the line is probably due to deep groundwaters with lower levels of stable isotopes than the measured values (Gat 1980). These deep waters have been warmed during their use in the City of Guelma, which explains their enrichment.

The graph showing the relationship between conductivity and oxygen 18 (Fig. 5), indicates a good relationship between the points $(16,18,28,29,39,43,46,47,48)$. This relationship shows that the increase in the conductivity of these waters is due to the dissolution. By comparison with the evaporated waters, we find six points $(16,39,43,46,47,48)$ where the mineralization is due to evaporation and dissolution. The other points $(11,34,40,41)$ are related to evaporation.

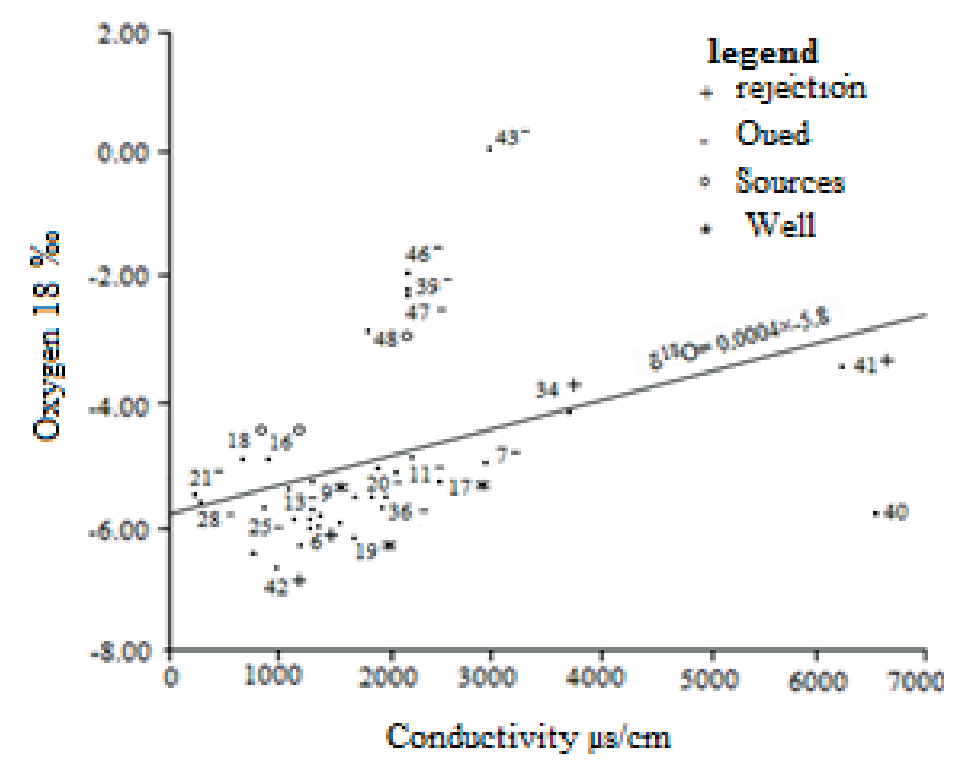

Fig. 5 The Oxygen 18-conductivity relationship.

\section{CONCLUSIONS}

Changes in mineralization are mainly due to the phenomena of surface or underground dissolution, infiltration and or warming phenomena at varying degrees during the surface water flow.

The relationship between the isotopic results and the location of water points throughout the studied area revealed two main areas:

- The field of homogeneous points including most of the samples. They have the same characteristics and are located between Guelma and Annaba, following Oued Seybouse.

- The evaporated water points field noted in the area of oued Meboudja. This is a channel drain for the lake Fetzara, which suggests a strong evaporation from it.

Note that the water used by the National Steel Company in their output is a bit warmer, which increases evaporation.

\section{REFERENCES}

Craig, H. and Cordon, L. I. (1965) Deuterium an oxygen 18 variations in the ocean and marine atmosphere. In: Stable Isotopes in Oceanography Studies and Paleotemperatures. Laboratorio di Geologia Nucleare, Pisa, 9-130.

Djabri, L. (1996) Mechanism of Seybouse water pollution and venerability-geological, industrial, agricultural and urban origins. Doctoral thesis, University of Annaba, p. 176

Fontes, J. C (1976) Isotopes du milieu et cycles des eaux naturelles, quelques aspects. Thèse de dotorat ès-Sciences, Université Paris VI, $128 \mathrm{p}$.

Gat, J. R (1980) The isotopes of hydrogen and oxygen in precipitation. In: Handbook of Environmental Isotope Geochemistry. Vol. I, Ed Elsevier, Amsterdam, 227-258.

Hani, A. (2003) Methodological examination of anthropological structure and process, application for Mediterranean coastal basin water sources. Doctoral thesis, University of Annaba, 213p.

Souag, M. (1989) Tracing of natural waters by environmental isotopes $\mathrm{O}^{18}, \mathrm{H}^{2}$ and tritium. National Conference on Applications of Nuclear Radiation and radioisotopes.

Zenati, N. (1999) Aquifer-lake relation, hydrochemistry confirmation. West plain of El-Hadjar Superficial aquifer case, Fetzara Lake, Algerian NE. Master Degree thesis, University of Annaba, 148 p, 